\title{
特集 脑神経機能温存
}

\section{傍前床笑起内頸動脈溜と視機能温存}

卯田健井上亨

\section{Preserving Visual Function in the Surgical Treatment of Paraclinoid Aneurysms \\ by}

Ken Uda, M.D., and Tooru Inoue, M.D.

from

Department of Neurosurgery, Clinical Research Institute, National Hospital Organization, Kyushu Medical Center

The microsurgical anatomy of the paraclinoid area and the surgical approach to paraclinoid aneurysms were reported. Aneurysms arising from the ICA between the site of its exit from the roof of the cavernous sinus and the origin of the posterior communicating artery have been termed paraclinoid aneurysms. Direct surgery of paraclinoid aneurysms requires an anterior clinoidectomy for adequate exposure of the paraclinoid space. The optic nerve is typically displaced superomedially by the aneurysm which often results in visual deficits. To preserve visual function, intraoperative damage to the optic nerves needs to be minimized and proper attention must be paid to safeguard the ophthalmic artery and superior hypophyseal artery. We examined the causes of optic nerve injuries and described useful methods to preserve the visual function

(Received October 22, 2007; accepted November 21, 2007)

Key words : aneurysm, internal carotid artery, visual function, anterior clinoidectomy, optic nerve Jpn J Neurosurg（Tokyo） $17: 107-113,2008$

\section{はじめに}

傍前床突起内頸動脈瘤の定義は，報告者によって若干 の相違があるが, 通常は内頸動脈硬膜輪から後交通動脈 分岐部までの内頸動脈から発生した動脈溜と考えてよ (23)8111)17).これは ophthalmic segment の動脈瘤とほぼ一 致する. Ophthalmic segment から眼動脈と上下垂体動脈 が分岐するが，この部位から発生する動脈瘤はこれらの 分枝と無関係に発生する例も多い.このことが, 傍前床 突起内頸動脈瘤の定義に若干の混乱を招いている要因で ある。この傍前床突起内頸動脈瘤の直達手術は, 視神経 周囲に最も多く接近する手術の一つであり，手術合併症 としての視神経損傷が問題となることも少なくない。ま
た，視神経を強く圧迫，あるいは伸展しているような大 型の内頸動脈瘤の場合は, 視機能の回復や温存が課題と なる.傍前床突起内頸動脈瘤を安全に手術するためには, 海綿静脈洞・前床突起近傍・ carotid dural ring • carotid caveの微小解剖に習熟し, 手術合併症を最小限にするよ う心がけねばならない2910)。傍前床突起内頸動脈瘤にお ける視神経障害の原因を検討し, 視機能温存のための工 夫について報告する。

\section{内頸動脈と視神経}

内頸動脈は，前床㔖起の内側で硬膜を貫いて硬膜内頭 蓋へ入る. 貫通する部分の硬膜は, carotid dural ring と

独立行政法人国立病院機構九州医療センター脳神経外科・臨床研究部 $/$ T10-8563 福岡市中央区地行浜 1-8-1〔連絡先：卯田 健]

Address reprint requests to: Ken Uda, M.D., Department of Neurosurgery, Clinical Research Institute, National Hospital Organization, Kyushu Medical Center, 1-8-1 Jigyohama, Chuo-ku, Fukuoka-shi, Fukuoka 810-8563, Japan 

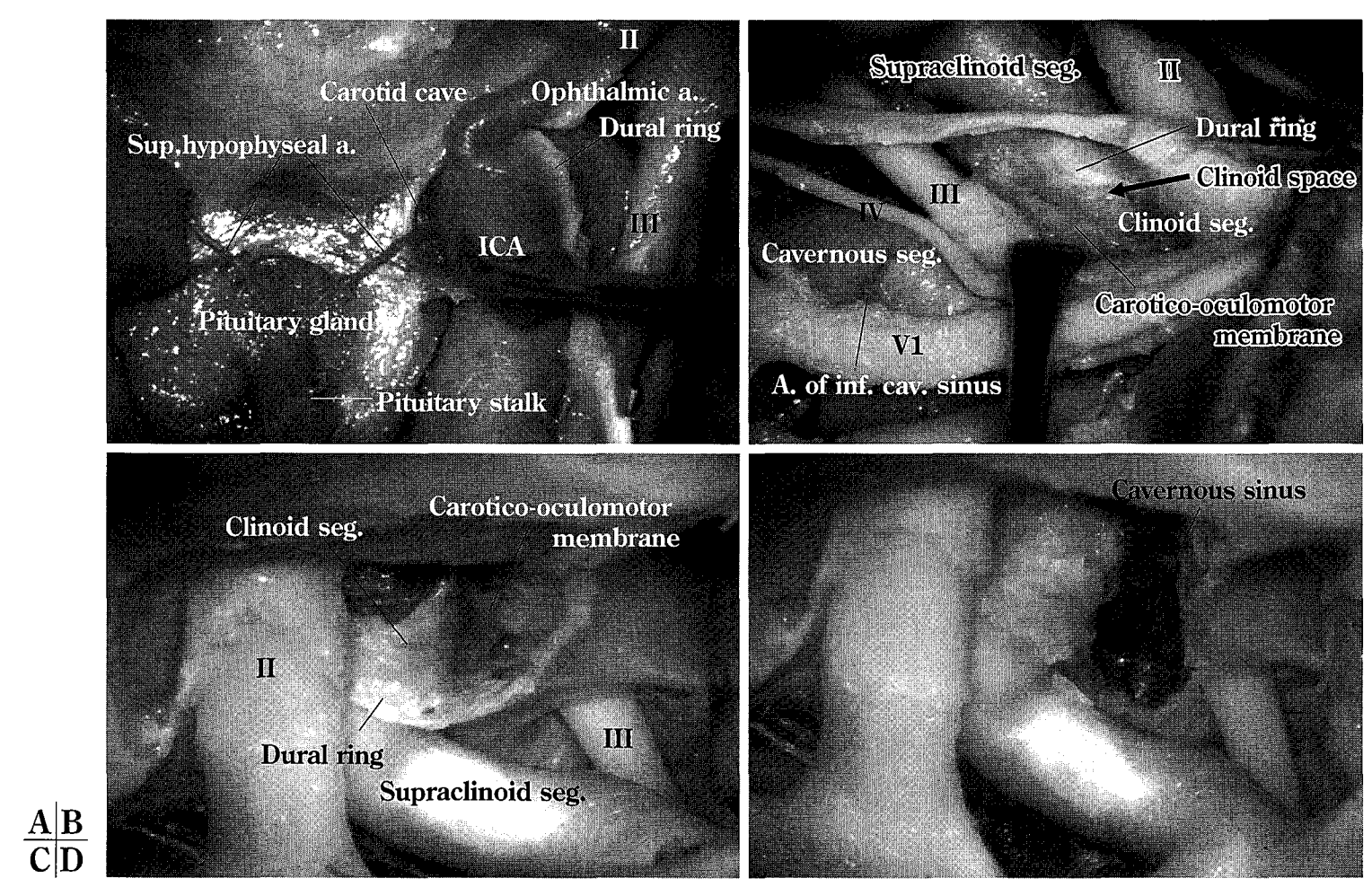

Fig. 1 A : Superior view of the right paraclinoid area. The anterior clinoid process was removed.

B : The anterior clinoid process has been removed to expose the clinoid space. A cuff of dura, called the dural ring, extends around the ICA at the level of the roof of the cavernous sinus.

$\mathrm{C}$ : Removal of the anterior clinoid process exposes the clinoid space and the caroticooculomotor membrane.

D : Removal of the carotico-oculomotor membrane exposes the cavernous sinus.

呼ばれる硬膜輪を形成する。眼動脈は，内頸動脈が硬膜 輪を貫いて硬膜内頭蓋へ入った直後に内頸動脈の上内側 から分岐する．視神経管内には硬膜に被われた視神経が あり，視神経の下側に眼動脈がある。硬膜輪の外側は内 頸動脈と強固に結合しているが, 内側は鞍隔膜へと連続 する間に狭いポケット状の陥凹を有している（Fig. 1A）。 この陥凹部は硬膜内腔の連続であり, carotid cave と呼ば れる. Carotid cave 部の内頸動脈から上下垂体動脈が分岐 し，視神経，視交叉，下垂体柄，鞍隔膜を栄養する，視 神経管入口部にある鋭い硬膜のヒダを falciform ligament (dural fold) と呼ぶ.

\section{Carotid dural ring と clinoid space}

前床笑起を削除した後に得られる空間は内頸動脈の外 側部であり, clinoid space と呼ばれる。この空間は硬膜 外・海綿静脈洞外であり,ここに露出される内頸動脈(外 側部の露出) は $5 \mathrm{~mm}$ 程度の長さがあり, clinoid segment と呼ばれる (Fig. 1B). 前床突起の外側下方には動眼神 経がある。Clinoid spaceの遠位部境界は前述の硬膜輪 (carotid dural ring) があり, 硬膜内腔と分離されている
が，近位部は carotico-oculomotor membrane と呼ばれる 膜で海綿静脈洞と境界されている。この膜は前床突起の 骨膜と連続した結合組織であり, 内頸動脈の前垂直部外 側と動眼神経の間に張った膜である。図でわかるように 実際には完全なリング状にはなっていないが，これを便 宣的に proximal ring と呼び (Fig. 1C)，これに対して硬 膜輸を distal ring と呼ぶこともある. Carotico-oculomotor membraneにより clinoid space は海綿静脈洞と隔て られているため, 前床突起削除の際にこの膜を破らない かぎり海綿静脈洞は開放されない（Fig. 1D).

\section{手術手技}

傍前床㚙起内頸動脈瘤の手術に際して, 視機能障害の 原因は, 視神経への血行障害あるいは機械的損傷と考え られる。視機能温存を目指し視神経に低侵襲となるよう に配慮し手術を行うことは非常に重要である ${ }^{18)}$. 視機能 障害の原因となる要因を検討し, 視神経に低侵襲となる ように配慮した点を述べる。

はじめに, 頸部で頸動脈を確保する、前頭側頭開頭を 行った後, 上眼窩裂が開放されるまで, 眼窩上壁や蝶形 

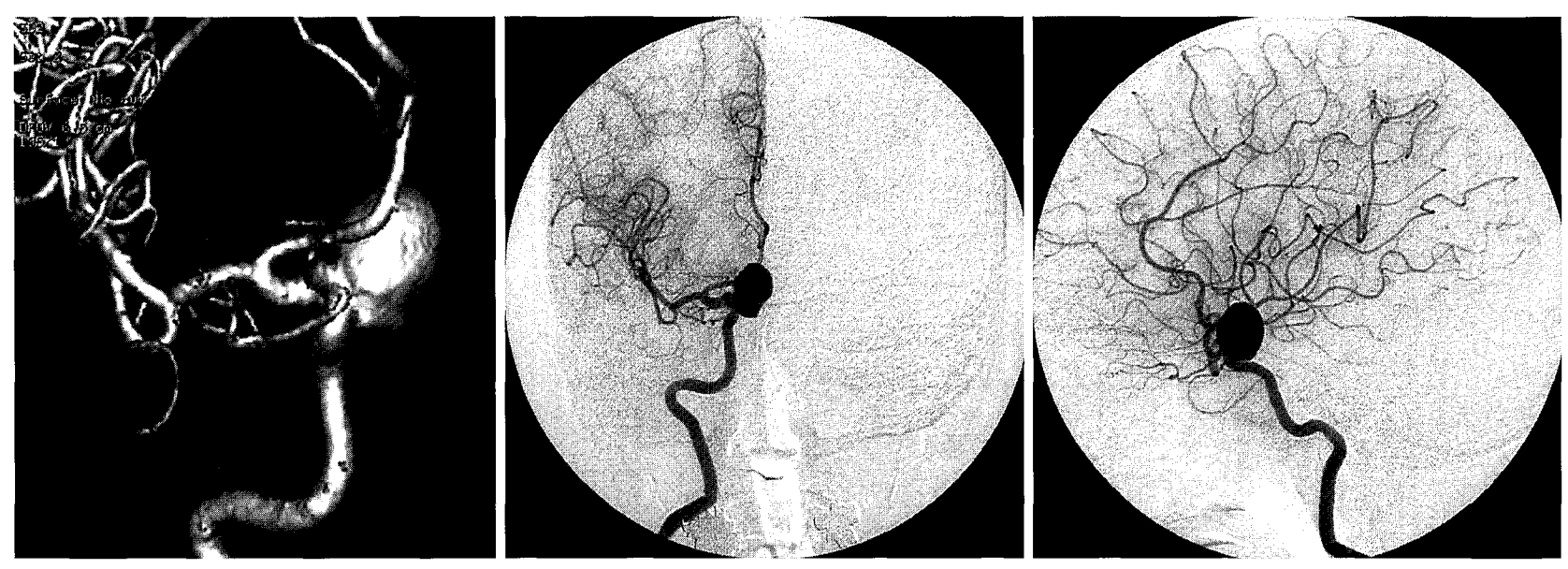

$\underline{\mathrm{A}|\mathrm{B}| \mathrm{C}}$ Fig. 2 3D-angiogram, A-P view and lateral view of a preoperative right carotid angiogram demonstrated a carotid-ophthalmic large aneurysm.
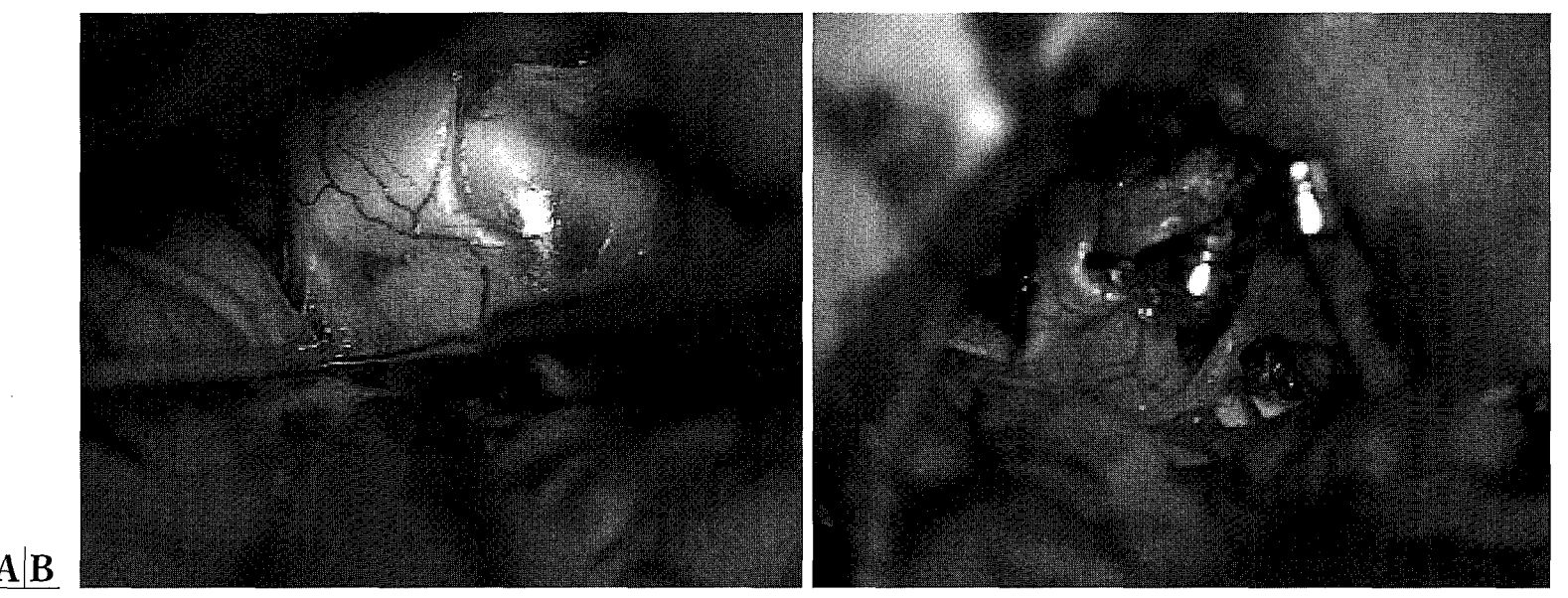

Fig. 3 Intraoperative photographs

A : The aneurysm was exposed by right pterional craniotomy with the sylvian fissure widely open.

B : Neck clipping of the aneurysm was performed.

骨小翼の骨は可及的に削り取る，多方向からの操作を可 能とするため，シルビウス裂は十分広く開ける．視神経 外側前床哭起は，基本的に硬膜内で削除する，削る部分 を覆う硬膜を少し大きめに切開後剝離し, 手前に翻転し, 脳実質，視神経，眼動脈を保護し，注意しながら骨用ソ ノペットを用いて削除する．前床笑起が除去された跡は 薄い膜で覆われており，これが保たれているかぎり海綿 静脈洞からの出血はないが, 破れた場合はサージセルを 詰めることで止血は可能である. Falciform ligament で視 神経が折れ曲がって損傷されるのを防ぐために, 視神経 管の開放を近位側から遠位側に向けて行う．Falciform ligamentから始まる視神経の dura propia 視神経に 沿って開放し, 視神経を内側に圧排することによって, 眼動脈分岐部と内頸動脈，動脈溜との関係をみることが できる. 硬膜輪 (carotid dural ring) は切開, 開放する. クリッピングに際しては, 頸部で確保した頸動脈の遮断
により，動脈瘤の圧を減弱させて行う，内頸動脈の血流 を障害しないように血管形成的にクリップをかける，必 要ならば, suction decompression を考慮する。眼動脈と 上下垂体動脈の温存に努める.クリップは空付きのク リップを用いる機会が多い. 空の部分で視神経が圧排さ れることがあるので, 空の径が小さいクリップを選択し たり視神経管を十分に開放することで, 視神経の損傷を 回避する，動脈瘤の頸部が広い例では，内頸動脈の狭窄 や直線化が起きやすいので, 術中 DSA で確認する。 あ らかじめ頸部頸動脈が露出されており, 比較的短時間に 血管撮影を行うことができる. クリッピング後, 脳へら を外し前頭葉が元の位置に戻った時に, クリップが偏位 しないか，またクリップヘッドが視神経を圧迫していな いか注意する，場合によっては前頭葉下面のクモ膜と軟 膜を切開してクリップヘッドが収まる間隙を作る工夫が 必要である。 


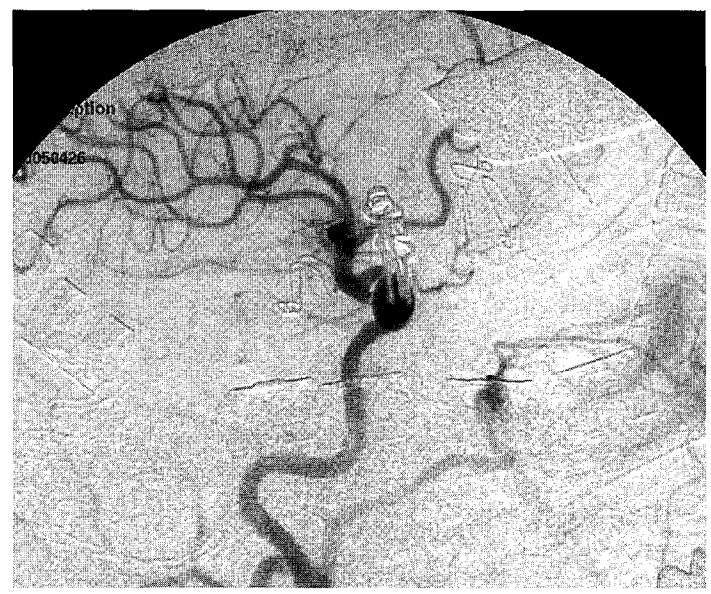

Fig. 4 Operative carotid angiogram showing that the aneurysm has disappeared and the patency of the ICA.

\section{症例提示}

患 者: 60 歳，女性

主 訴: 視力・視野障害

現病歴： 2004 年 9 月頃より右視力・視野障害が出現 し，2005 年 4 月 5 日，多発脳動脈瘤を指摘され当科紹 介入院となった.

神経学的所見: 視力 右 0.3 , 左 0.6 , 視野 右眼内側下 $1 / 4$ 盲.

術前放射線学的評価：脳血管撮影（Fig. 2) で動脈溜の 最大径は $15 \mathrm{~mm}$ で, blebを伴っており, ドームは内側 上方に突出しており, 視交叉部方向に伸展していた. 3DCT では, 動脈瘤内の血栓や動脈瘤の石灰化などは認め なかった。

手 術: 術前, 動脈瘤により視神経・視交叉を内側上 方に圧排していることが予想された。まず，右頸部で内 頸動脈を確保した。右前頭側頭開頭でシルビウス裂を末 梢より大きく開放した。内頸動脈に大きな動脈瘤を認め, 動脈瘤により右視神経は強く内側上方へ圧排されてい た. 右視神経管および前床突起を骨用ソノペットで削除 した，眼動脈起始部が確認できたが, 視神経は動脈瘤に より紙状に薄く引き延ばされており, 動脈瘤のドームと 強く癒着していた。内頸動脈を一時的に遮断した後, 視 神経との間に隙間を作り, 直クリップと有空クリップで neck clipping を行った (Fig. 3). 術中 DSA で, 眼動脈が 温存され内頸動脈の狭窄がないことを確認した (Fig. 4). 術後 2 週間目の視力は, 右光覚, 左 0.1 , 術後 4 力月目 の視力は, 右 0.5 , 左 1.0 , 視野 右半盲, 術後 9 力月目 の視力は, 右 1.0 , 左 1.2, 視野正常と, 一時的に視交叉 ならびに右視神経障害を認めた（Fig. 5）。
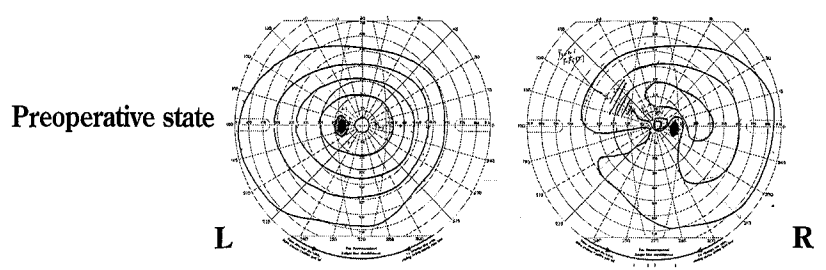

14 days after operation

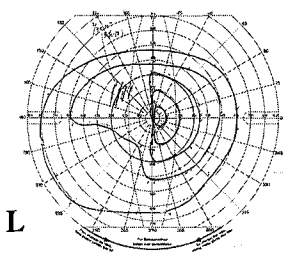

Almost blind

$\mathbf{R}$

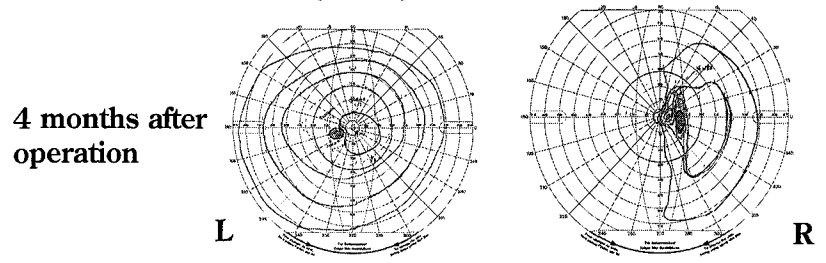

9 months after operation

Visual field: normal

Fig. 5 Postoperative course of visual acuity and visual field

A : Preoperative state: visual acuity, $\mathrm{L} / \mathrm{R} 0.6 / 0.3$, visual field $: \mathrm{R}:$ inferior nasal quadrant defect

B : 14 days after operation; $\mathrm{L} / \mathrm{R} 0.1 /$ blindness

C : 4 months after operation; L/R $1.0 / 0.5$, visual field : R: nasal hemianopsia

9 months after operation: L/R 1.2/1.0, visual field: normal

\section{視機能障害の要因に対する考察と視機能温存}

\section{1 皮膚弁による眼球圧迫}

翻転した皮虐弁や手術器具による眼球の圧迫が原因で 失明することがある、皮弁を強く引き過ぎないようにし， 引く方向にも注意し, 眼球が圧迫されていないことを確 認する必要がある。

\section{2 前頭側頭開頭に伴う中硬膜動脈から視神経へ の血行障害}

一般的な前頭側頭開頭であり，特に変わりはない，心 がけていることは，蝶形骨縁を十分に除去することであ る.上眼窩裂の外側縁を確認し，さらに奥まで削除する。 この操作により術野が広がり, 手術操作がやりやすくな る．注意すべきことは，稀に眼動脈が中硬膜動脈の分枝 である recurrent meningeal artery から栄養されている場 合があり，このような例では上眼窩裂まで骨切除を行う と recurrent meningeal artery を損傷してしまい, 失明の 危険が指摘されている ${ }^{16)}$. 内頸動脈の眼動脈枝が無形成 あるいは退化し，眼動脈の血液供給がすべて外頸動脈由 来の症例が存在する。これまでの報告によると，外頸動 

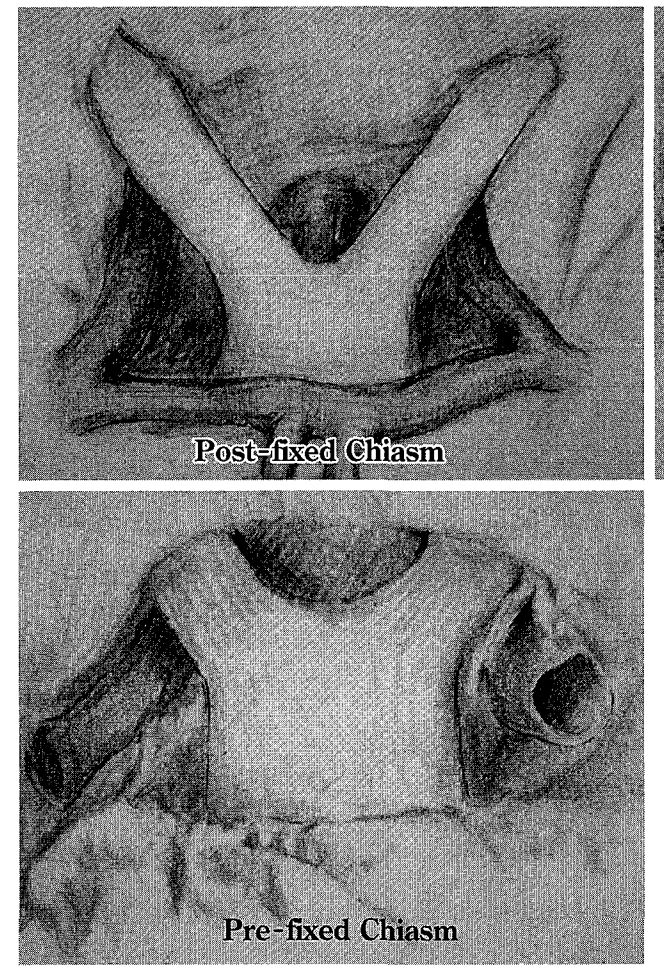

脈由来の眼動脈例の比率は約 1 2\%とされている.この 割合から考元ると, 術後の視力障害が他の原因によるも のとされている可能性があり, 実際にはより多くの脳神 経外科医によって経験されている可能性がある。術前の 脳血管撮影における眼動脈の確認はいうまでもなく, 特 に眼動脈が内頸動脈から分岐していない症例において外 頸動脈撮影は重要であり, 開頭時に蝶形骨縁の削除の際 に外頸動脈系血管の損傷に配慮した手術方針を立てる必 要がある.

\section{3 手術操作に伴う視神経損傷}

傍前床突起内頸動脈瘤と称される動脈溜に対する直達 手術においては, 視神経周囲は最も接近する部位であり, 手術操作に伴う視神経損傷は重要な問題である. 直達手 術における視神経に対する愛護的な操作はもとより, 視 神経に極力触らず治療が完了すれば理想的である。しか しながら, 動脈瘤の全貌を露出して, クリップの㨂入を 可能とするためには, 前床突起の削除と視神経管開放が 必要とされる。

前床突起の削除に骨用ソノペットを用いた，(1)従来の 高速回転ドリルに比べ，装置に触れても硬膜が損傷され ないこと, (2)綿花などを巻き込まないので視神経を含め た周囲組織を綿花で保護することにより安全に使用可能 であること, (3)摩擦熱が発生するが冷却のための生理食 塩水が先端から供給され助手の水やりが不要なこと, (4) 自動吸引できることなどの点で有用であった ${ }^{10)}$ 。まだま

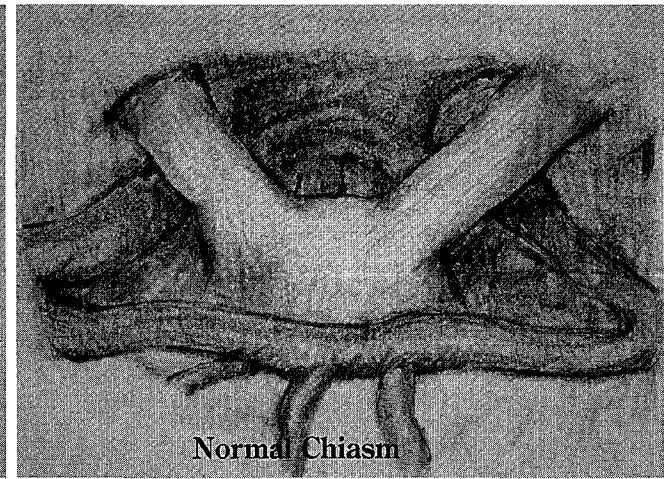

\section{\begin{tabular}{l|l}
$\mathrm{A}$ & $\mathrm{B}$ \\
\hline $\mathrm{C}$ &
\end{tabular}}

Fig. 6 Chiasmatic configuration

Pre-fixed chiasm (15\%), Normal chiasm $(70 \%)$, Post-fixed chiasm (15\%).

だ先端のサイズ，装置の長さ，形状など種類が少ないこ とや，骨用ソノペットを視神経管開放術に使用し，視野 障害の合併症が生じた例の報告もあり ${ }^{1)}$, 使用には十分 な注意が必要であることはいうまでもない.

視神経の可動性を增すための操作において chiasmatic configuration は重要な要素であると考える(Fig. 6). Prefixed chiasm は約 15\%, normal chiasm は約 70\%, postfixed chiasm は約 15\%に存在するとされている ${ }^{13)}$. Prefixed chiasm の場合, 視神経の可動域は制限され, 大き な動脈瘤の場合, 視交叉部での損傷の可能性も出てくる. 視神経を長く露出し, falciform ligament の切開を行い, 視神経の可動性を増すことは, 術中操作の機械的損傷か ら守る方法として重要である. Evans らの報告)による と, 前床突起削除により視神経の長さは約 2 倍となり, 視神経の可動性の回旋性が増すこととなる。また, 内頸 動脈硬膜輪を全周性に切開すると, 内頸動脈の内外側へ の自由度が増して視神経に対する圧排が軽減される。そ れらの操作に伴う視神経損傷の頻度は $3 \%$ との報告もあ $\eta^{7)}$, 視神経損傷を回避する手技は重要である。手術操 作による視神経損傷という観点からすると, 内頸動脈瘤 の内側向きの動脈瘤に関しては対側からのアプローチも 報告されており, 視神経に優しい, 視神経に対して低侵 襲な手術といえる ${ }^{19)}$.さらに視神経圧迫症状，あるいは 圧迫所見を有する大型一巨大脳動脈瘤に対する直達手術 の場合には, 視機能が術後に悪化することが約 $20 \%$ に達 すると報告されている ${ }^{6)}$. 大きな動脈瘤の場合, 動脈瘤 
のネック部の剝離, 確保の際に視神経に加わる圧排が強 くなる可能性があり, 術後視神経障害をきたしやすい.

今回提示した症例では, 視神経は動脈瘤により紙状に 薄く引き延ばされており，動脈瘤のドームと強く癒着し ていた。頸部内頸動脈を一時的に遮断し動脈瘤の圧を減 じ，動脈瘤と視神経の㔀離を行った。しかしながら，術 後, 視野, 視力障害が出現した。術中に眼動脈起始部は 確認できており，また十分な上下垂体動脈の確認はでき なかったが，明らかな視神経・視交叉の栄養血管の損傷 がなかったことから，視神経・視交叉の機械的損傷と考 えられる，本症例のように，動脈瘤が比較的大きく視神 経が菲薄化している場合や動脈箇との強い癒着がある場 合は, 視機能の改善のための十分な減圧はもとより, 圧 排伸展されて脆弱となった視神経に対する機械的損傷を 避けるために工夫が必要とされ，その一つとして動脈瘤 の直接穿刺や内頸動脈からの留置カテーテルによる evacuation technique は有用である。

手術によって出現した視力障害は回復するか? この 命題に対してのまとまった報告はないのが現状である. 術前の視力障害が中等度で, 先に述べた視神経に対して 低侵襲な手術手技を用いれば，視神経の機械的損傷によ る視機能障害は, 提示した症例のように数力月〜 1 年以 内に回復する可能性がある ${ }^{18)}$. また, 術前に手動弁以下 の高度視力障害があり, 症状発現から数力月以上経過し た症例で, なおかつ手術所見で視神経が動脈瘤により著 明に菲薄化している症例では, 術後視神経障害が出現し やすく回復が困難である ${ }^{2)}$ ，視神経を栄養する硬膜枝な どの血行障害による視機能障害は失明に至り, 回復が困 難であるとの報告がある ${ }^{14)}$. 一方, 術前存在していた視 機能障害の回復について, 伊達ら ${ }^{2)}$ は, 硬膜輪近傍の大 型, 巨大動脈瘤であっても, 発症から 3 力月以内に外科 的治療しえれば，視機能障害の改善が期待できるとして いる．また，動脈瘤の壁の性状に関連した視機能障害の 報告もあり，動脈瘤壁に石灰化を伴うものや溜内血栓を 伴う動脈瘤では, 術後に視機能の悪化をきたす可能性が ある ${ }^{12)}$.このような動脈瘤の直達手術は, いまだ困難な 治療といえよう。そのため, 直達手術よりも proximal occlusion+bypass 手術や血管内塞栓術の有用性も報告さ れている.

\section{4 眼動脈閉塞による視神経障害}

眼動脈の急性閉塞による失明の危険性は約 $10 \%$ とい わ机ている ${ }^{515)}$. 眼動脈は, 通常内頸動脈から分肢する が，外頸動脈系の血管ともさまざまな吻合がみられる。 内頸動脈の硬膜枝が視神経を栄養し, その損傷で失明し
たとの報告もある ${ }^{14)}$. 血行障害による視神経機能障害は 不可逆的である可能性があり,十分な注意が必要である.

\section{5 上下垂体動眽閉塞による視神経障害}

上下垂体動脈閉塞による合併症は，これまでほとんど 報告されていない.上下垂体動脈は平均 1 本の内頸動脈 に約 2 本 (1〜 5 本) あり, 内頸動脈の内側ないし後壁か ら分岐する. 硬膜内内頸動脈のより近位部に多く存在し, 80\%の例では内頸動脈から出ている. 下垂体柄の周囲に 血管網（circuminfundibular anastomosis）を形成し，視交 叉下面にも分布する。上下垂体動脈は，1本のみ犠牲に しても症状が出ることはほとんどない。しかしながら， 複数の上下垂体動脈を同時に閉塞した場合は, 視神経・ 視交叉栄養障害をきたす可能性があり，また一時的な下 垂体機能不全を呈することもあり，眼動脈はもとより上 下垂体動脈も可能なかぎり温存に孥めるべきであろう. 同側からのアプローチの場合, 上下垂体動脈の確認が困 難なことも多く, 有品クリップで容易に上下垂体動脈の 閉塞をきたしうるので注意を要する。また，内側向きの 大きな動脈瘤の場合, 下垂体柄は動脈瘤の後方, 内側に 圧排偏移していることがあり ${ }^{3)}$, 剝離の際注意すべきで ある。

\section{結 語}

傍前床突起内頸動脈瘤の直達手術における視機能障害 の原因は, 開頭に伴う眼球圧迫, 中硬膜動脈の血行障害, falciform ligament による視神経損傷, 手術操作に伴う視 神経損傷，眼動脈，上下垂体動脈閉塞による視神経栄養 障害などが挙げられる。視神経障害を軽減させるための 操作として, 視神経を被う falciform ligament の切開, 視 神経管の開放, 前床突起の削除, 親動脈の一時的遮断, 動脈瘤の穿刺吸引など，視神経に対して低侵襲となる方 法を工夫し, 視機能を温存することは非常に重要である.

\section{文 献}

1) Abe $T$, Satoh $K$, Wada $A$ : Optic nerve decompression for orbitofrontal fibrous dysplasia : Recent development of surgical technique and equipment. Skull Base 16:145-155, 2006.

2）伊達 勲, 大本蓱史：直接クリッピング術を施行した硬 膜輪近傍の大型 -巨大内頸動脈塯の検討. 脳卒中の外科 31: 295-302, 2003.

3) Day AL: Aneurysms of the ophthalmic segment. A clinical and anatomical analysis. J Neurosurg 72:677-691, 1990.

4) Evans JJ, Hwang YS, Lee JH : Pre- versus post-anterior clinoidectomy measurements of the optic nerve, internal carotid artery, and opticocarotid triangle : A cadaveric mor- 
phometric study. Neurosurgery $\quad 46: 1018-1023,2000$.

5) Ezura M, Takahashi A, Yoshimoto $T$ : Combined intravascular parent artery and ophthalmic artery occlusion for giant aneurysm of the supraclinoid internal carotid artery. Surg Neurol $47: 360-363,1997$.

6) Feruguson GG, Drake CG: Carotid-ophthalmic aneurysms: The surgical management of those cases presenting with compression of the optic nerves and chiasm alone. Clin Neurosurg 54:275-276, 1980.

7) Hoh BL, Carter BS, Budzik RF, Putman CM, Ogilvy CS : Results after surgical and endovascular treatment of paraclinoid aneurysms by a combined neurovascular team. Neurosurgery $48: 78-90,2001$.

8) Iihara K, Murao K, Sakai N, Shindo A, Sakai H, Higashi T, Kogure S, Takahashi JC, Hayashi K, Ishibashi T, Nagata I: Unruptured paraclinoid aneurysms: A management strategy.J Neurosurg 99:241-247, 2003.

9) Inoue $T$, Rhoton AL Jr, Theele D, Barry ME: Surgical approaches to the cavernous sinus: A microsurgical study. Neurosurgery 26:903-932, 1990.

10) 井上 亨, 卯田 健, 佐山徹郎, 勝田俊郎, 佐藤裕一郎: Paraclinoid aneurysm の外科治療一前床突起切除におけ る骨切除用超音波手術装置（ソノペット）の有用性一. 顕微鏡下手術のための脳神経外科XVII。東京, サイメッ ド・パブリケーションズ, 2004, pp.71-75.

11) Kobayashi S, Kyoshima K, Gibo H, Hegde SA, Takemae T, Sugita $\mathrm{K}$ : Carotid cave aneurysms of the internal carotid artery. J Neurosurg $\quad 70: 216-221,1989$.

12）野中 雅, 大滝雅文, 上出延治, 田邊純嘉, 端 和夫： 内頸動脈一眼動脈分岐部動脈瘤手術例における視機能回 復の問題点. 脳卒中の外科 $25: 352-358,1997$.

13) Rhoton AL Jr, Hardy DG, Chambers SM: Microsurgical anatomy and dissection of the sphenoid bone, cavernous sinus and sellar region. Surg Neurol 12:63-104, 1979.

14) Rizzo JF 3rd: Visual loss after neurosurgical repair of paraclinoid aneurysms. Ophthalmology 102: 905-910, 1995.

15) Shaibani A, Khawar S, Bendok B, Walker M, Russell EJ, Batjer HH: Temporary balloon occlusion to test adequacy of collateral flow to the retina and tolerance for endovascular aneurysmal coiling. AJNR Am $J$ Neuroradiol 25: 1384-1386, 2004.

16）島 克司，川崎 剛，清水 昭，瀧口博司，千ヶ崎裕夫： Pterional approach に合併した眼動脈閉塞による失明の 1 例と回避し得た 2 例の検討。脳外誌 4:163-169, 1995.

17）塩川芳昭, 齋藤 勇: Carotid ring 近傍の脳動脈瘤の分類 と治療. 脳卒中の外科 $25: 359-364,1997$.

18）田辺英紀，住岡真也，池永 透，島野裕史，安田宗一郎， 渡部啄治, 横山邦生, 近藤明息: 視神経障害に注意が必 要な脳動脈溜手術における低侵襲手術。脳卒中の外科 34: 420-427, 2006.

19）田中雄一郎，本郷一博，多田 剛，北沢和夫，高沢尚能， 伊泊広二, 宮入洋祐, 小林茂昭: Paraclinoid 内頸動脈溜を 安全に露出する方法. 脳卒中の外科 31：117-120, 2003.

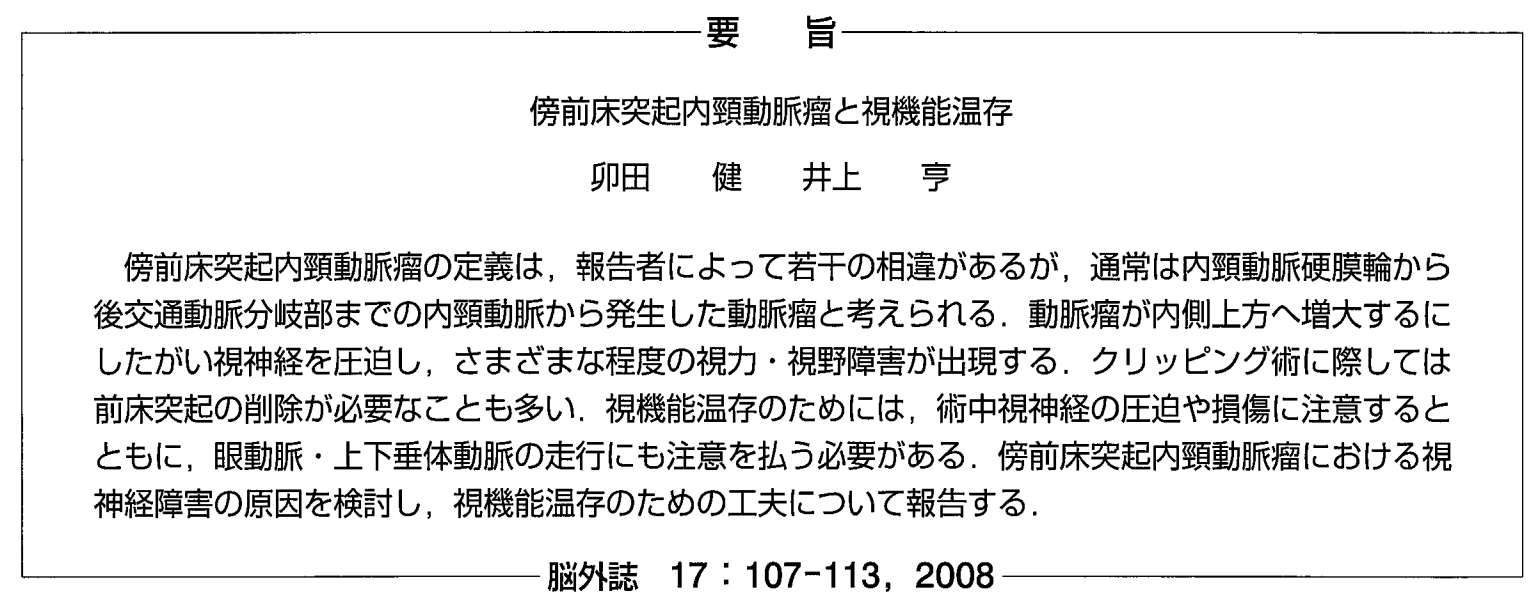

